\title{
一般口演 3
}

\section{上下畨間の厚さ弁別能に関する研究 一小臼歯部での検討一}

\begin{abstract}
A study on the thickness discrimination ability between maxillary and mandibular teeth at the premolar region
\end{abstract}

\author{
○串奈津貴, 築山能大, 古谷野 潔 \\ Natsuki Okushi, Yoshihiro Tsukiyama, Kiyoshi Koyano \\ 九州大学大学院歯学研究院口腔機能修復学講座咀嚼機能再建学分野 \\ Department of Removable Prosthodontics, Faculty of Dental Science, Kyushu University
}

\section{I. 緒 言}

客観的に明らかな咬み合わせの異常が認められない にも関わらず，咬み合わせの違和感や不都合を訴える患 者を経験することがある，咬み合わせの違和感の原因に は, 歯䯣炎や歯周病, 早期接触などが考えられる。 また, 精神医学的な問題によっても症状が引き起こされている 可能性も少なくない.これらの原因の他に咬み合わせの 違和感を生じるものとして, 咬合の高さを認識する咬合 感覚センサーの異常によって生じている可能性も考えら れる. しかし, 過去に咬合の高さを認識する咬合感覚セ ンサーに関する報告はあるものの, 臨床的に有用な報告 は十分ではない.

そこで本研究は, 咬合感覚異常における咬合感覚セン サーの関与の可能性を検討することを目的とする.すな わち, 健常者および咬合感覚異常者の厚さ弁別能を客観 的に評価し，それらを比較することにより咬合感覚異常 に扔ける弁別能の特性を明らかにする.

我々はこれまでに, 健常有歯顎者の上下顎中切歯間に おける厚さ弁別能について報告してきたが, 今回は健常 有歯顎者の小臼歯部における厚さ弁別能について計測を 行ったので報告する.

\section{II. 方 法}

被験者に20歳代の健常有歯顎者14名を選択した。試験 には厚さ $2,5,10 \mathrm{~mm}$ のステンレス製のスタンダードブ
ロック（SB）と SBから $\pm 0.25 \mathrm{~mm}$ 刻みで厚さの異なる 12 種類のテストブロック（TB）を用いた。なお， TBの 厚みは $\mathrm{SB}$ の厚みより最大で士 $1.50 \mathrm{~mm}$ 異なる.

計測では，他の知覚の影響を可及的に避けるために， 被験者に口角鈎・eye-mask · ear-plug を装着させた.ま ず SBを上顎第一小臼歯に接触させ約 2 秒間弱い力で咬 ませた後に, SBを除去し, 約 2 秒後に TBを $\mathrm{SB}$ 同様 の手順で咬ませた、TBを除去した後, 被験者に TBの 厚みがSBに比べて「厚い」と感じるか，あるいは「薄 い」と感じるかを手指で合図させ，その結果を記録し た.この操作をすべての TBについて繰り返し行った. なお，TBの順番は系統的な誤差を排除するために，乱 数表を用いて無作為に決定した.これを 1 日 1 回 $(2,5$, $10 \mathrm{~mm} \times 2 \mathrm{set})$, 計 3 日間計測した.

解析は，厚い TBを薄い, 薄い $\mathrm{TB}$ 厚いと答えた場 合を誤答とし, 誤答数を算出して行った.

\section{III. 結 果}

「薄い」 $\mathrm{TB}$,「厚い」 $\mathrm{TB}$ の影響の違いをみるため に, 2, 5, 10mmの SBそれぞれについて「薄い」 TB 群 と「厚い」 TB 群とで誤答数の比較を行ったところ, す べてのSBにおいて「厚い」TB群と「薄い」TB群との 間に統計学的な有意差が認められた $(\mathrm{P}<0.05$, $\mathrm{t}$-test)（図 $1)$.

また, SBの厚さの影響をみるために, $2,5,10 \mathrm{~mm}$ で誤答数の比較を行ったところ, $2 \mathrm{~mm}$ と $5 \mathrm{~mm}, 5 \mathrm{~mm}$ 

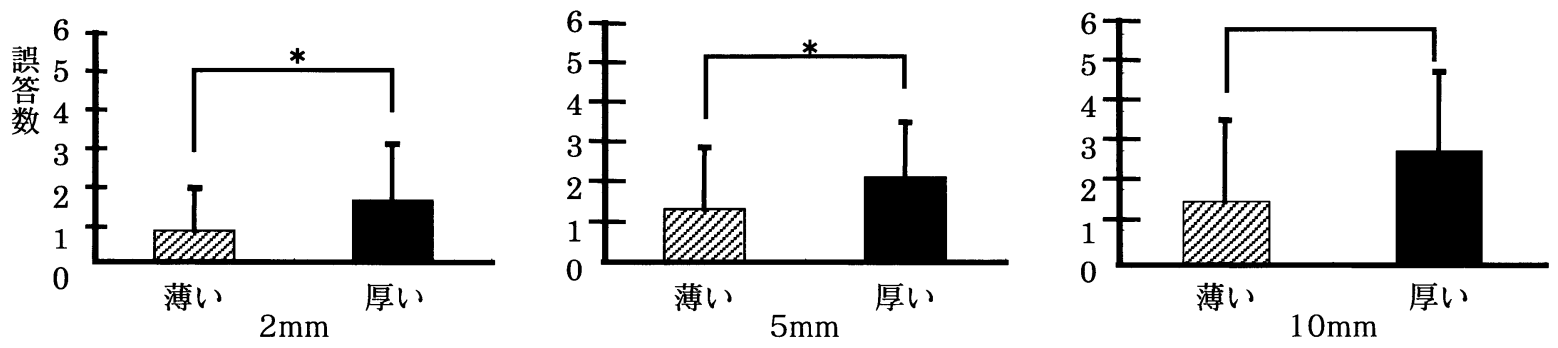

図 1 TBの「薄い」,「厚い」の影響

$*: \mathrm{P}<0.05, \mathrm{t}$-test $; \mathrm{n}=14$

と $10 \mathrm{~mm}$ の間には統計学的な有意差は認められなかった が， $2 \mathrm{~mm}$ と $10 \mathrm{~mm}$ の間には統計学的な有意差が認めら れた（P<0.05, ANOVA; Scheffe）（図 2$)$.

\section{N. 考察}

今回の結果は, Takagiら (1979), Morimotoら (1977) の報告と使用したブロックの厚みは異なるものの同様の 傾向を示した。 また，以前我々が報告した前歯部の厚さ 弁別能とも同様の結果を示している.

このことから，前歯部および小臼歯部の厚さ弁別能に は同様のメカニズムが関与していることが示唆された.

\section{V. 文献}

1) Takagi M, Kobayashi J. Studies on the inter dental thickness discrimination of objects. Jap J Prosthet Dent 1979; 23: 629-633.

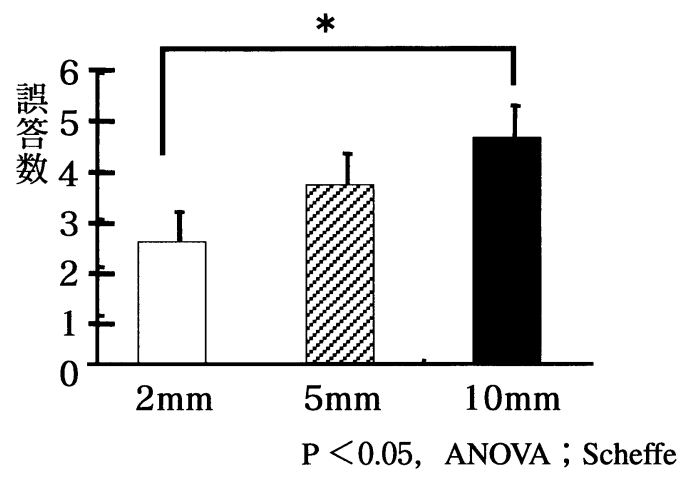

図 2 SBの厚さの影響

2 ) Christnsen J, Morimoto T. Dimension discrim ination at two different degrees of mouth opening and the effect of anaesthesia applied the periodontal ligaments. J Oral Rehabil 1979; 4: 157-164. 